IRSTI 17.82.10

\author{
Alpysbayeva A.E. ${ }^{1}$, Mehmet G. ${ }^{2}$, Ashymkhanova S.A. ${ }^{3}$, \\ ${ }^{1} 1$ year doctoral student of Al-Farabi Kazakh National University, Almaty, Kazakhstan, \\ ${ }^{2}$ Dr., Associate Professor of Haci BayramVeli University, Turkey, Ankara, \\ ${ }^{3}$ Doctor of Science, Professor of Al-Farabi Kazakh National University, Kazakhstan, Almaty, \\ e-mail: aygul.alpysbaeva.91@mail.ru,gulsunn.mehmet@gmail.com, svetlana-1943@mail.ru
}

\title{
TRANSLATION OF THE CULTURE-BEARING SYMBOLISM OF ANIMALS IN THE POEM «TURKESTAN» OF MAGZHAN ZHUMABAYEV (Turkish, Russian and English languages)
}

The article discusses translation features of animals' symbolism in the poem «Turkestan» of kazakh poet Magzhan Zhumabayev. The author analyzes the translation of the words of symbols into Turkish, Russian and English languages based on the linguocultural aspect of the translation. Conclusions are made on the basis of the analysis of the translation of words that bear not only symbolic but also cultural significance. If the translation of linguistic and cultural information into other languages and the level of its reception by the reader is one of the topical issues of translation studies, the creativity and translation of Magzhan's poetry which is the culmination apogee of Kazakh symbolism still requires research.

The article uses for the first time translations into Turkish and English by Professor of the center for European, Russian and Eurasian studies Timur Kodjaoglu of the University of Michigan. It also analyses the translation of the Turkic linguist, academician Farhat Tamer, and translation of Bauyrzhan Dzhilkibaev in Russian.

Key words: artistic translation, a source text, a target text, culture, history, poetry, linguoculturology, symbolic words, symbolism of animals.

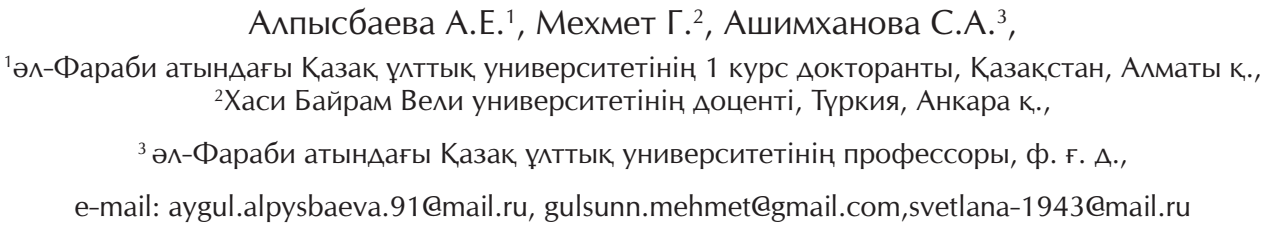

А^пысбаева А.Е. ${ }^{1}$, Мехмет Г. ${ }^{2}$, Ашимханова С.А. ${ }^{3}$, əл-Фараби атындағы Қазақ ұлттық университетінің 1 курс докторанты, Қазақстан, Алматы қ.,

\section{М. Жұмабаевтың «Түркістан» өлеңіндегі мәдени мәнге ие аңдар символикасының аударылуы (түрік, орыс, ағылшын тілдері)}

\footnotetext{
Мақалада қазақтың дара ақыны Мағжан Жұмабаевтың «Түркістан» өлеңіндегі аңдар символикасының аударма ерекшеліктері қарастырылады. Нақтырақ айтқанда, ақын қолданған символ сөздердің түрік, орыс және ағылшын тілдеріне аударылуының лингвомәдени аспектісі негізге алынады. Яғни, тек символикалық емес, мәдени мәнге сөздердің аудармада қандай көрініс тапқаны талданып, тұжырым жасалған. Аингвомәдени ақпараттың басқа тілге тәржімалануы, оны оқырманның қабылдау деңгейі аударматанудың өзекті мәселелерінің бірі болса, отты жырлары қазақ символизмінің апогейі болып табылатын Мағжан ақын шығармашылығы және оның аудармалары әлі де зерттеуді қажет етеді. А^ғаш рет Мичиган университетінің «Еуропа, орыс және еуразиялық зерттеулер» орталығының профессоры Тимур Коджауглының түрік және ағылшын тілдеріндегі аудармалары қарастырылған. Сондай-ақ түрік мингвисі, академик, мағжантанушы Фархат Тамердің аудармасы, орыс тілінде Б. Жылқыбаевтың аудармалары талданған.

Түйін сөздер: көркем аударма, түпнұсқа, аударма мәтіні, мәдениет, тарих, поэзия, мингвомәдениеттану, символ сөздер, аңдар символикасы.
} 


\begin{abstract}
А^пысбаева А.Е. ${ }^{1}$, Мехмет Г. ${ }^{2}$, Ашимханова С.А. ${ }^{3}$,
1Аокторант 1 курса Казахского национального университета имени аль-Фараби, Казахстан, г. А^маты, ${ }^{2}$ Аоцент университета Хаси Байрам Вели, Турция, г. Анкара,

${ }^{3}$ А.ф.н. профессор Казахского национального университета имени аль-Фараби, Казахстан, г. А^маты, e-mail: aygul.alpysbaeva.91@mail.ru, gulsunn.mehmet@gmail.com, svetlana-1943@mail.ru
\end{abstract}

\title{
Перевод культуроносной символики животных \\ в стихотворении М. Жумабаева «Туркистан» (турецкий, русский и английский языки)
}

\begin{abstract}
В статье рассматривается особенности перевода символики животных в стихотворении «Туркестан» казахского поэта Магжана Жумабаева. Автор делает анализ перевода слов символов на турецкий, русский и английский языки, основываясь на мингвокультурном аспекте перевода. САеланы выводы на базе анализа перевода слов, которые несут не только символическое, но и культурное значение. Если перевод лингвокультурной информации на другие языки и уровень ее рецепции читателем является одним из актуальных вопросов переводоведения, то творчество и переводы поэзии Магжана, которая является кульминационным апогеем казахского символизма, все еще требует исмледования.

В статье впервые используются переводы на турецкий и английский языки просессора Центра «Европейского, русского и евразийского исследования» Тимура Кожаоглу Мичиганского университета. Также анализируются переводы тюркского ^ингвиста, академика Фархата Тамера, и перевод Бауыржана Ажилкибаева на русском языке.
\end{abstract}

Ключевые слова: художественный перевод, исходный текст, культура, история, поэзия, мингвокультурология, слова символы, символистика животных.

\section{Introduction}

«In the autumn of 1892 Valery Bryusov, the leading poet of the Silver age, found the heuristic word «symbolism». There were no signs then that in one of the colonial border regions of Russia through the year the child was born, who grew up and after some two decades as a student of the Moscow Higher literary-art Institute, led by the same Bryusov, would stand before him fully formed symbolist, who opened a new path for the Kazakh poetry.» (Kanarbayeva, 2007: 37) This is about famous Kazakh poet, symbolist Magzhan.

Magzhan Zhumabayev is an outstanding Kazakh writer, poet, and publicist, one of the founders of the new Kazakh literature. His poems, stories are characterized by acute tragedy, expressing a sense of responsibility to the people and the ensuing appeal to the origins and turning points of history. At the same time, Magzhan embraced the universal artistic and scientific heritage, starting with Shakespeare, Pushkin, Solovyov and ending with symbolism, technocracy and Spengler. Existential motifs are quite clearly visible in his work.

But first and foremost it is obvious to mention that his poetic feat is impressive. Fate gave him only fifteen years for creative work. The remaining years of his forty-four-year life, apart from the childhood and adolescence, took place in Stalin's prisons and camps, where the poet did not return. In that short time, he made a name for himself.
Not every talent is destined to determine the theme and problems of literature for many years to come. Even under the strictest ban, his creations influenced the search for national literature. Now, in the conditions of freedom of creativity the unique poetic context created by him has opened as if the second breath. And his poetry spreads its wings across the expanses of many countries. So, after many years of silence Magzhaan Zhumabayev opened to us anew. Nowadays his work is being translated into different foreign languages of the world.He is a poet who belongs to all mankind. Such is Magzhan, who occupies his strong place in the elite number of artists of the word.

\section{Experiment}

In the far abroadmost of all, the life and work of the great Kazakh poethave been studied in Turkey, where «Magzhan's days» were held. On creativity of Magzhan Zhumabayev many scholars did research and wrotethesis. In short, until recently, the poet was revered in Turkey more than in his Homeland. There are some reasons for this. In his youth Magzhan sent a poetic greeting to «distant relatives», as he called the people of the Turks. When the national liberation war of the Turks led by Kemal Pasha was played out in earnest, the Turkish theme sounded especially loudly in the works of Magzhan. These ties between the poet and the Turkic people were forever fixed 
thanks to his poem «Turkestan», in which the poet praises the entire Turkic people and perceives all the Turkic peoples as one.«Turkestan» became not only valuable heritage of national literature, but also Turkic peoples and the world.And translations of this poem in Turkish by F. Tamir, T. Kojaoglu, in Russian by B. Dzhilkibaev and in English by T. Kojaoglu served as a research material. The used methods: description, identification, comparative analysis, problem-thematic, cognitive analysis and generalization.

\section{Results and discussion}

The poem includes different types of information: cultural, historical and social. On the one hand it makes it meaningful and valuable, but on the other hand very difficult for translation. Translation of words of reality, historicism, symbols and proper names requires deep background knowledge and pre-translation analysis. There are some key, basic cultural words that play important role to understand the idea of the poem and author's intention. One of these words are symbols that poet often used.Not in vain the ardent poetry of Magzhan called the culminating climax of the Kazakh symbolism. The search for new ways of depiction, in all probability, led him to symbolism, which also claimed the role of a holistic worldview, promised to expand the possibilities of human thinking by activating the unconsciousness. Especially in the poetry of author is frequently found symbolism of animals and this poem is not exception. For example, M. Zhumabayev used several times a word «kokzhal» (nominative meaning 'kok' - blue, 'zhal' - mane) that bears symbolic meaning:

\begin{tabular}{|c|c|}
\hline The source text & Interlinear translation \\
\hline $\begin{array}{l}\text { Тұранның теңіздерлік көлдері бар, } \\
\text { Шалқыған егі-шетсіз Теңіз, Арал. } \\
\text { Бір шетте қасиетті Ыстықкөлдің } \\
\text { Бауырында дүние көрген түрік көкжал. } \\
\text { (Zhumabayev, 1989: 169) }\end{array}$ & $\begin{array}{l}\text { In Turan there are lakes like the sea, } \\
\text { Extend the vast Tengiz, the Aral sea. } \\
\text { In one edge of Saint Issyk-Kul } \\
\text { Seen the light Turk kokzhal. }\end{array}$ \\
\hline $\begin{array}{l}\text { Шыңғыстан Шағатай, Үкітай, Жошы, Төле } \\
\text { Атаға тартып туған бәрі бөрі. } \\
\text { Шыңғыстың қол бастаған екі көзі - } \\
\text { Жолбарыс Сұпытай мен көкжал Жебе. } \\
\text { (Zhumabayev, 1989: 170) }\end{array}$ & $\begin{array}{l}\text { From Genghis, Chagatay, Oktay, Chochi, and Toli } \\
\text { All wolves born similar on ancestors. } \\
\text { Two eyes of Genghis who led the military - } \\
\text { Tiger Subudai and kokzhal Zhebe. }\end{array}$ \\
\hline $\begin{array}{l}\text { Тұраннан Сарыарқаны бөлек деме, } \\
\text { Түркістан алты алашқа болған Кебе. } \\
\text { Тұранның топырағын құшып жатыр } \\
\text { Кешегі ердің ері көкжал Кене. } \\
\text { (Zhumabayev, 1989: 170) }\end{array}$ & $\begin{array}{l}\text { Do not say that Turan is separate from Saryarka } \\
\text { Turkistan was Kebe to six Alash } \\
\text { Turan's earth embraced } \\
\text { Yesterday's kokzhal Kene, the hero of the heroes }\end{array}$ \\
\hline
\end{tabular}

According to explanatory dictionary 'kokzhal is a mother wolf, the leader of the wolf pack; the literal translation is gray mane' (Alimbay, 2011: 97) Butits cultural and symbol icmean in gtakesroot from antiquity. L. Gumilev, a scientist who studied the history of the ancient Turks, wrote in one of his works that the ancient Turks called the Wolf «Kok Kurt». «Kok» means bright blue, blue, and celestial. The Turkic word «Kurt»is the root of the Kazakh word «kurtulu» (salvation, deliverance). That is, the blue wolf is a sacred animal for the Turks, the messenger of the God of heaven Kok Tengri, who saved their tribes from death (Gumilev: nomadkazakhstan.kazakh.ru/nomad-kazakhstan/590. php).The idea of the saving mission of the Wolf was reflected in many ancient Turkic legends and written monuments. In the epic «Oguznama» Oguz-
Kagan before going on a campaign, addresses to the tribesmen with such speech: «I became your Kagan, we will take bows and boards, let there will be to you "grace», «Blue Wolf»let it be the motto» (battlecry).In addition, in the days of the ancient Turks wolf heads of bronze, gold and silver served not only as the finial of the banner, but also the decoration of horse lashes, Psalms, weapons, belts. This is eloquently evidenced by archaeological finds on the lands of the great ancient Turkic Khaganate. Objects with the image of the wolf were attributes of power and symbols of nobility, courage, high origin, they had a ritual meaning of the sacred protection of the spirit of the Wolf.

And poet used this symbolic word as a defining attribute of common name 'Turk kokzhal' and proper names 'kokzhal Zhebe', 'kokzhal Kene', showing 
the special role of these people, their strength and power and the greatness of the whole nation. In this way Magzhan conveyed the importance of these people in one word. This shows not only how the author is well versed in the history and culture of the
Turkic people, but also the power of the meaning of the word.

Now let us consider how this symbolic word was translated into other languages. The first table contains translation in Russian:

\begin{tabular}{|c|c|c|}
\hline The source text & Interlineartranslation & Dzhilkibaev's translation into Russian \\
\hline $\begin{array}{l}\text { Тұранныңтеңіздерліккөлдері бар, } \\
\text { Шалқығанегі-шетсізТеңіз, Арал. } \\
\text { БіршеттеқасиеттіЫстықкөлдің } \\
\text { Бауырындадүниекөрген түрік көкжал. } \\
\text { (Zhumabayev, 1989: 169) }\end{array}$ & $\begin{array}{l}\text { In Turan there are lakes like the sea, } \\
\text { Extend the vast Tengiz, the Aral sea. } \\
\text { In one edge of Saint Issyk-Kul } \\
\text { Seen the light Turk kokzhal. }\end{array}$ & $\begin{array}{l}\text { А озера твои, как моря, глубоки! } \\
\text { Вот безбрежный Арал - гордость } \\
\text { Сары-Арки! } \\
\text { На твоих берегах, о святой Иссык- } \\
\text { Куль, } \\
\text { Синих тюрков Отчизна ковала клинки. } \\
\text { (Zhumabayev, 2003: 44) }\end{array}$ \\
\hline $\begin{array}{l}\text { Шыңғыстан Шағатай, Үкітай, Жошы, } \\
\text { Төле } \\
\text { Атаға тартып туған бәрі бөрі. } \\
\text { Шыңғыстың қол бастаған екі көзі - } \\
\text { Жолбарыс Сұпытай мен көкжал Жебе. } \\
\text { (Zhumabayev, 1989: 170) }\end{array}$ & $\begin{array}{l}\text { From Genghis, Chagatay, Oktay, Chochi, } \\
\text { and Toli } \\
\text { All wolves born similar on ancestors. } \\
\text { Two eyes of Genghis who led the } \\
\text { military - } \\
\text { Tiger Subudai and kokzhal Zhebe. } \\
\end{array}$ & $\begin{array}{l}\text { А потомки Чингиза есть волки в седле: } \\
\text { Шагатай, Укитай и Жучи, и Туле. } \\
\text { Два лихих полководца, два глаза } \\
\text { Чингиза: } \\
\text { Субудай - старый тигр и бесстрашный } \\
\text { Жебе. (Zhumabayev, 2003: 45) } \\
\end{array}$ \\
\hline $\begin{array}{l}\text { Тұраннан Сарыарқаны бөлек деме, } \\
\text { Түркістан алты алашқа болған Кебе. } \\
\text { Тұранның топырағын құшып жатыр } \\
\text { Кешегі ердің ері көкжал Кене. } \\
\text { (Zhumabayev, 1989: 170) }\end{array}$ & $\begin{array}{l}\text { Do not say that Turan is separate from } \\
\text { Saryarka } \\
\text { Turkistan was Kebe to six Alash } \\
\text { Turan's earth embraced } \\
\text { Yesterday's kokzhal Kene, the hero of the } \\
\text { heroes }\end{array}$ & No translation \\
\hline
\end{tabular}

So in Russian we can see such transformations of symbolic words: 'Turk kokzhal' become 'Синие тюрки' (blue Turks), 'kokzhal Zhebe' become 'бесстрашный Жебе' (fearless Zhebe). There is also frequently used connotation like 'blue Turks'. But 'blue' and 'kokzhal' are not the same, although both of them havea symbolic meaning associated with the Turks.Just above we have analyzed the cultural and symbolic meaning of the word «kokzhal». How about 'blue'? Turks' blue contains mythological (in mythological consciousness the sky has always been the abode of gods, spirits of ancestors; hence the main symbol of blue - divinity. Lord of heaven), spiritual (in order to understand the faith of the ancient Turks, it is worth a closer look at the area of their settlement. The first archaeological finds of the remains of this ethnos were found in Central Asia - the land of endless steppes and clear, sparkling blue sky. It is from the «mood» of the heavens depended on the life of the nomadic tribe. The sun was warm, the rain gave the moisture, and the lightning was often the cause of fires. Therefore, the main deity was the sky - Tengri, father-protector, the masculine, the Creator of all things. It was believed that the deity lives on one of the peaks of the Tien Shan, the highest point of modern Kazakhstan. This pyramidal peak is called Khan-Tengri, the Lord of the sky(Who was worshipped by the Turks before Islam: https://news.rambler.ru/other/39949795komu-poklonyalis-drevnie-tyurki-do-prinyatiyaislama/), symbolical (the symbolism of blue comes from an obvious physical fact - the blue of the cloudless sky) contexts. We can notice some universal contexts of perception of the blue color in case of the worship of heaven, symbolizing of the sky.In the monument of Turkic runic writing «KulTegin» and «Bilge-Kagan» Turks called themselves «Blue Turks». But in this case we mean neither the name of the color, but the cosmic meaning «sky». Therefore, it is correct to understand it as «celestial Turks» instead of «blue Turks» (The Blue Turks: https://egemen.kz/article/kok-turikteri).

To conclude we find that 'kok' (blue)and 'kokzhal' can not substitute each other even though they both relate with Turks.

In comparison with Russian in English translator used nominal meaning of 'kokzhal', so we can see 'the blue-maned Turk', 'blue-maned Zhebe' and 'bluemaned Kene'. It lost its symbolic shape and quality and that distorts receptor's deep understanding of the source text. To avoid such difficulties sometimes it is suitable to give transliteration of cultural words 
and to make a note in the form of explanation or interpretation. Since the Kazakh and Turkish languages are related, and the peoples have related roots, in their language picture of the world there is an understanding of «kokzhal», the both translations do not raise any questions at the level of the receptor.

\begin{tabular}{|c|c|c|c|}
\hline The source text & $\begin{array}{c}\text { Timur Kocaoglu's translation } \\
\text { into English }\end{array}$ & $\begin{array}{c}\text { Timur Kocaoglu's translation } \\
\text { into Turkish }\end{array}$ & $\begin{array}{c}\text { Farhat Tamir's translation } \\
\text { into Turkish }\end{array}$ \\
\hline $\begin{array}{l}\text { Тұранның теңіздерлік көлдері } \\
\text { бар, } \\
\text { Шалқыған егі-шетсіз Теңіз, } \\
\text { Арал. } \\
\text { Бір шетте қасиетті } \\
\text { Ыстықкөлдің } \\
\text { Бауырында дүние } \\
\text { көрген түрік көкжал. } \\
\text { (Zhumabayev,1989: 169) }\end{array}$ & $\begin{array}{l}\text { Turan has lakes as large as a } \\
\text { sea: } \\
\text { The Aral, the stormy and } \\
\text { endless sea. } \\
\text { In the bosom of the sacred Lake } \\
\text { Issik } \\
\text { The blue-maned Turk was born. } \\
\text { (Kojaoglu, 2018: } 36 \text { ) }\end{array}$ & $\begin{array}{l}\text { Turanniñ teñizderlik kölderi } \\
\text { bar, } \\
\text { Şalqiğan egi-şeksiz Teñiz, Aral. } \\
\text { Bir şette qasietti Istiqköldiñ } \\
\text { Bawirinda dünye körgen Türik } \\
\text { kökjal. (Kojaoglu,2018: 38) }\end{array}$ & $\begin{array}{l}\text { Toranniñ teñiz derlikkölderi } \\
\text { bar, } \\
\text { Çalqiğan egi-çeksiz teñiz, Aral. } \\
\text { Bir çette kasiyetti Istik Köldiñ } \\
\text { Bavirinda dünye körgen Türik } \\
\text { kökcal. (Tamir, 1993: 268) }\end{array}$ \\
\hline $\begin{array}{l}\text { Шыңғыстан Шағатай, Үкітай, } \\
\text { Жошы, Төле } \\
\text { Атаға тартып туған бәрі бөрі. } \\
\text { Шыңғыстың қол бастаған екі } \\
\text { көзі - } \\
\text { Жолбарыс Сұпытай } \\
\text { мен көкжал Жебе. } \\
\text { (Zhumabayev,1989: 170) }\end{array}$ & $\begin{array}{l}\text { From Genghis, Chagatay, } \\
\text { Oktay, Chochi, and Toli } \\
\text { Were born as wolves like their } \\
\text { father. } \\
\text { The two eyes of Genghis that } \\
\text { he entrusted } \\
\text { Were the tiger Supitay } \\
\text { and the blue-maned Jebe. } \\
\text { (Kojaoglu,2018: 40) }\end{array}$ & $\begin{array}{l}\text { Şinğistan Şağatay, Őktay, Joşi, } \\
\text { Töle. } \\
\text { Atağa tartip tuwğan bäri böri. } \\
\text { Şinğistan qol bastağan eki közi } \\
\text { Jolbaris Supitay men Kökjal } \\
\text { Jebe. (Kojaoglu,2018: 41) }\end{array}$ & $\begin{array}{l}\text { Çinğis'tanÇağtay, Öktay, Çoci, } \\
\text { Töle. } \\
\text { Atağa tartip tuvğan bèri böri. } \\
\text { Cinğis’tinkol bastağan eki közi } \\
\text { Colbaris Supitay men kökcal } \\
\text { Cebe. (Tamir,1993: 268) }\end{array}$ \\
\hline $\begin{array}{l}\text { Тұраннан Сарыарқаны бөлек } \\
\text { деме, } \\
\text { Түркістан алты алашқа } \\
\text { болған Кебе. } \\
\text { Тұранның топырағын құшып } \\
\text { жатыр } \\
\text { Кешегіердің ері көкжал Кене. } \\
\text { (Zhumabayev, 1989: 170) }\end{array}$ & $\begin{array}{l}\text { Don't speak of the steppes as } \\
\text { outside of Turan } \\
\text { Turkistan gave birth to the Six } \\
\text { Alash } \\
\text { The hero of heroes, Blue- } \\
\text { maned Kene } \\
\text { Has been caressing the soil of } \\
\text { Turan. (Kojaoglu,2018: 40) }\end{array}$ & $\begin{array}{l}\text { Turannan Sari Arqani bölek } \\
\text { deme, } \\
\text { Türkistan alti Alaşka bolğan } \\
\text { kebe. } \\
\text { Turanniñ topirağin quşip jatir } \\
\text { Keşegierdiñ eri Kökjal Kene. } \\
\text { (Kojaoglu,2018: 41) }\end{array}$ & $\begin{array}{l}\text { Torannan Sari Arka'nibölek } \\
\text { deme, } \\
\text { «Türkistan» alti Alaç'ka bolğan } \\
\text { kebe. } \\
\text { Toran'niñ toprağin quçip catir } \\
\text { Keçegierdiñ eri kök-cal Kene. } \\
\text { (Tamir, 1993: 270) }\end{array}$ \\
\hline
\end{tabular}

Except for this Magzhan actively used universal symbolistic animals like a lion, a tiger, and a wolf to describe people and to show their character:

\begin{tabular}{|l|l|}
\hline \multicolumn{1}{|c|}{ The source text } & \multicolumn{1}{|c|}{ Interlinear translation } \\
\hline $\begin{array}{l}\text { Шыңғыстай арыстанның құратыда } \\
\text { Адамның жүрегіне жігер берер. (Zhumabayev, 1989: 170) }\end{array}$ & $\begin{array}{l}\text { Just name of the lion like Genghis } \\
\text { Gives strength to the human heart. }\end{array}$ \\
\hline $\begin{array}{l}\text { Шыңғыстан Шағатай, Үкітай, Жошы, Tөле } \\
\text { Атаға тартып туған бәрі бөрі. (Zhumabayev, 1989: 170) }\end{array}$ & $\begin{array}{l}\text { From Genghis, Chagatay, Oktay, Chochi, and Toli } \\
\text { All wolves born similar on ancestors. }\end{array}$ \\
\hline $\begin{array}{l}\text { Шыңғыстың қол бастаған екі көзі - } \\
\text { Жолбарыс Сұпытай мен көкжал Жебе. (Zhumabayev, 1989: 170) }\end{array}$ & $\begin{array}{l}\text { Two eyes of Genghis who led the military - } \\
\text { Tiger Subudai and kokzhal Zhebe. }\end{array}$ \\
\hline $\begin{array}{l}\text { Apыстан елге Отан болған Тұран, } \\
\text { Тұранда қазағымда хандық құрған. (Zhumabayev, 1989: 171) }\end{array}$ & $\begin{array}{l}\text { Turan, which was the Fatherland of the lion people, } \\
\text { And my Kazakh built a khanate in Turan }\end{array}$ \\
\hline $\begin{array}{l}\text { Тұранның топырағында тыныштық тапқан } \\
\text { Алаштың арыстаны - Абылай ері... (Zhumabayev, 1989: 171) }\end{array}$ & $\begin{array}{l}\text { The lion of Alash - hero Abylay } \\
\text { Who found peace in the earth of Turan }\end{array}$ \\
\hline
\end{tabular}

\section{Conclusion}

That was only about translation of symbolism of animals that bear cultural meaning. As it was mentioned in the early beginning of this article the poem «Turkestan» is full of significant cultural and historical information which will be devoted to the following articles and studies. And we certainly be- 
lieve that the work of the poet and translations will be studied not only in the frame of the national literature. The following statements serve only as confirmation of this. Professor K. Makhmudov, an ethnic Tatar, just noticed: «...The influence of Magzhan Zhumabayev is not limited by the national framework. Magzhanov poetic culture, his high skill had a beneficial effect not only in the Kazakh poetry, but also in the works of famous representatives of other Turkic peoples (Tatars, Uzbeks, Bashkirs)» (Eleukenov, 2007: 82).As it turned out, to translate poems of the Kazakh poet, who made an invaluable contribution to world civilization, T. Kojaoglu began in 1977. Two years after the independence of Kazakhstan, in 1993, he published the first book in which 7 poems of M. Zhumabayevwere translated.
Translation into English Professor makes in order to «the whole world find out about him». Over the next two years, Kojaoglu intends to translate another 40 verses of the outstanding Kazakh poet, and then release another book. "Poetry of Magzhan present dramatic voice. Heisabravemanwhoisfullyconfident in the correctness of the struggle against injustice, humiliation, bigotry and tyranny. The world community should continue to study the poetry of Magzhan, because his works have not been fully studied. I hope that the future generation will conduct an in depth study of his work» (The works of Magzhan Zhumabayev were presented at UNESCO: https:// www.inform.kz/ru/proizvedeniya-magzhana-zhumabaeva-prezentovali-v-yunesko_), - concluded T. Kojaoglu.

\section{Литература}

Қанарбаева Б. Мағжан символист: Зерттеу. - Алматы: Экономика, 2007. - 288 б.

Жұмабаев М. Шығармалары. - Алматы: Жазушы, 1989. - 448 б.

Әлімбай Н. Қазақтың этнографиялық категориялар, ұғымдар мен атауларының дәстүрлі жүйесі. - Алматы: «Б.о.ж», 2011. - 7366.

Гумилев Л. Культ волка в мифологии древних тюрок. Онлайн журнал «Nomad Kazakhstan». - 2018. - 13 мая. http:// nomad-kazakhstan.kazakh.ru/nomad-kazakhstan/590.php 13 Мая 8:55

ЖумабаевМ. Пророк: Стихи и поэмы. Пер. с каз. / Сост., вступ. ст., коммент. Канапьянова Б.; Худож. Наурызбаев Н. М.: Русская книга, 2003. - 176 с. (2003. Год Казахстана в России)

Кому поклонялись тюрки до принятия ислама? Интернет-газета «Рамблер». - 2018. - 26 мая.

https://news.rambler.ru/other/39949795-komu-poklonyalis-drevnie-tyurki-do-prinyatiya-islama/)

Сарай Ә. Көк түріктері//Онлайн газет «Егемен Қазақстан».-2011.-04қараша

https://egemen.kz/article/kok-turikteri.

Кожаоглу Т. Поэт пламени, свободы и любви. - Астана: Ғылым, 2018. - 85б.

Tamir F. Poems of M. Zhumabayev (Translation into Turkish). - Ankara, 1993. - 338p.

Елеукенов Ш. Магжан и современность. - Алматы: Алатау, 2007.- С. 80-92. - С. 80.

Произведения Магжана Жумабаева презентовали в ЮНЕСКО. - 2018. - 30 апреля https://www.inform.kz/ru/proizvedeniya-magzhana-zhumabaeva-prezentovali-v-yunesko_a3237115

\section{References}

Alimbay N. (2011). Qazaq etnografiyaliq kategoriyalar, ugimdar men ataulardyn dasturli zhuyesy. [Traditional system of Kazakh ethnigraphical categories, notions and names]. Almaty: «B.o.zh»,736 p. (In Kazakh)

Eleukenov Sh. (2007). Magzhanisovremennost. [Magzhan and modernity]. - Almaty: Alatau, P. 80-92. (In Russian)(90ygthghft07. C. $80-90$

Gumilev L.(2018). Kultvolka v mifologydrevnihturkov. [The cult of the wolf in the mythology of the ancient Turks]. Online journal «Nomad Kazakhstan».http://nomad-kazakhstan.kazakh.ru/nomad-kazakhstan/590.php. (In Russian)

Kanarbayeva B. (2007). Magzhan simvolist. [Magzhan symbolist]. Almaty: Economics, 288 p. (In Kazakh)

Komupokloniyalisturki do prinyatiyaIslama? [Who was worshipped by the Turks before Islam?]. Internet newspaper «Rambler». https://news.rambler.ru/other/39949795-komu-poklonyalis-drevnie-tyurki-do-prinyatiya-islama/. (In Russian)

Kojaoglu T. (2018). The poet of flame, liberty and love.Astana: Nauka, 85 p.

Proyzvedeniya Magzhana Zhumabayeva prezentovali v UNESCO. [The works of Magzhan Zhumabayev were presented at UNESCO]. International information agency «Kazinform»https://www.inform.kz/ru/proizvedeniya-magzhana-zhumabaeva-prezentovali-v-yunesko_a3237115.(In Russian)(90ygthghft07

Saray A. (2011). Siniyeturki. [The Blue Turks]. Online newspaper «Egemen Kazakhstan». https://egemen.kz/article/kok-turikteri. (In Kazakh)

TamirF. (1993) Poems of M. Zhumabayev (Translation into Turkish). Ankara, 338 p.

Zhumabayev M. (2003). Profet: Stihotvoreniya. [Prophet: Poems]. Translation from Kazakh.M.: Russkaiyakniga, 176 p. (In Russian)

Zhumabayev M. (1989). Shygarmalary. [Collected works]. Almaty: Zhazushi, 448 p. (In Kazakh) 